Article

\title{
Effect of Organic and Inorganic Fertilizers on the Yield and Quality of Jalapeño Pepper Fruit (Capsicum annuum L.)
}

\author{
Ana Alejandra Valenzuela-García ${ }^{1}$, Uriel Figueroa-Viramontes ${ }^{2}$, Enrique Salazar-Sosa ${ }^{3}$, \\ Ignacio Orona-Castillo ${ }^{4}$ (), Miguel Ángel Gallegos-Robles ${ }^{4}$, José Luis García-Hernández ${ }^{4}$ \\ and Enrique Troyo-Diéguez ${ }^{5, *}$ \\ 1 Institutional Posgraduate Program in Agriculture and Forest Science (DICAF), Juárez de Durango State \\ University (UJED), Constitución 404 Sur, Centro, Durango 34000, Dgo, Mexico; ale.valenzuela@ujed.mx \\ 2 La Laguna Experimental Station, INIFAP, Matamoros 27440, Coahuila, Mexico; urielfv@gmail.com \\ 3 Posgraduate and Research Department, Technological Institute of Torréon (ITT), \\ Torreón 27170, Coahuila, Mexico; enmageel1@yahoo.es \\ 4 Agriculture and Zootechnics Faculty, Juárez de Durango State University, Ejido Venecia, Tlahualilo Km 35, \\ Gómez Palacio 35111, Dgo, Mexico; orokaz@yahoo.com (I.O.-C.); garoma64@ujed.mx (M.Á.G.-R.); \\ luis_garher@hotmail.com (J.L.G.-H.) \\ 5 Center for Biological Research of Northwest Mexico, La Paz 23060, BCS, Mexico \\ * Correspondence: etroyo04@cibnor.mx; Tel.: +52-612-123-8484 (ext. 3442)
}

Received: 30 August 2019; Accepted: 16 September 2019; Published: 21 September 2019

\begin{abstract}
Organic fertilizers were evaluated on jalapeno pepper (Capsicum annuиm L.) and on their effect on the soil content of nitrogen $(\mathrm{N})$, phosphorus $(\mathrm{P})$, electrical conductivity $(\mathrm{EC}), \mathrm{pH}$ and organic matter $(\mathrm{OM})$, at the Experimental Station of the Agriculture and Zootechnics Faculty (FAZ-UJED), Ejido Venecia, Durango, México. The assayed experimental fertilizers were vermicompost (VC) with 0 and $3 \mathrm{Mg} \mathrm{ha}^{-1}$, in factorial combination with solarized manure (SM), with $0,40,80$, and $120 \mathrm{Mg} \mathrm{ha}^{-1}$, and an inorganic fertilization nitrogen-phosphorus-potassium (NPK) at $150-100-00 \mathrm{Mg} \mathrm{ha}^{-1}$. Microbiological analyses were performed to evaluate the presence of Salmonella spp. The highest yield was $56.2 \mathrm{Mg} \mathrm{ha}^{-1}$ with $120 \mathrm{Mg} \mathrm{ha}^{-1} \mathrm{SM}$, which was statistically similar to 40 and $80 \mathrm{Mg} \mathrm{ha}^{-1}$; the highest $\mathrm{P}$ content (70.7 $\mathrm{mg} \mathrm{kg}^{-1}$ ) and $\mathrm{OM}(3.7 \%)$ occurred with $120 \mathrm{Mg} \mathrm{ha}^{-1} \mathrm{SM}$. The inorganic fertilizer reflected the lowest OM (1.1\%). Nutrients provided by SM were sufficient to satisfy the crop needs. Values of $\mathrm{pH}, \mathrm{EC}$ and $\mathrm{N}$ were not affected by SM. The fruit quality was not affected by the organic fertilizers. Most fruits were classified as Second-Class Quality (60\%), followed by First-Class Quality (25\%). Microbiological analyses were negative for Salmonella spp., suggesting that the SM is effective in its elimination.
\end{abstract}

Keywords: manure; vermicompost; solarized manure; jalapeno pepper; jalapeno fruit; food safety

\section{Introduction}

The cultivation of peppers is considered an important issue to human food consumption. The world fresh pepper production in 2014 was at about 31,000,000 tonnes [1]. Mexico reached the second world place in 2014 as a green chili pepper producer, with a production volume of 2,700,000 tonnes on a harvested surface of 14,300 ha, while for 2018 the national production was estimated at 3,100,000 tonnes, with an average increase of $10.29 \%$ in four years [2]. Mexico is the first green chili pepper exporter in the world; the main export destinations are the United States and Canada. Among the principal chili pepper varieties cultivated in Mexico, we find the jalapeño pepper, serrano, habanero, poblano and morrón (bell pepper) [3]. 
The official agricultural SIAP on-line system (2016) reported a harvested surface of 637.8 ha and a production of $25,073.9 \mathrm{Mg} \mathrm{ha}^{-1}$ in 2015 for the Laguna-Durango District [4], in arid northern Mexico. Nowadays, the needs to reduce the costs associated with crop fertilization and the loss of soil fertility have raised interest and called the attention of producers regarding the use of organic amenders as alternative low-cost fertilizers. The above-mentioned has the purpose to supply the minimal nutritional requirements of crops, and moreover to promote higher yields and a better fruit quality, with lower impacts on the surrounding environment and natural resources, including the soil and water [5]. In the last decades, the organic substrates have been evaluated in different ways to establish their benefits in the development of the plants; accordingly, the yield of a crop such as the chili pepper depends on the nutritional balance, mainly $\mathrm{N}$ and $\mathrm{P}$ [6]. For a jalapeno pepper crop, a dose of $40 \mathrm{Mg} \mathrm{ha}^{-1}$ of solarized manure increased the yield by $5.98 \%$, compared with inorganic fertilization [7]. It is well documented that the yield of a crop after the incorporation of organic substrates is an adequate indicator of its benefits in relation to other variables. In this sense, the productivity of chili pepper crop with organic fertilization increased by $44 \%$, related by $34 \%$ to the final number of fruit, $40 \%$ to the length of the fruit and $26 \%$ to the diameter with organic fertilization compared to inorganic fertilization [5].

The organic matter content must be considered when planning the use of organic fertilizers; Vázquez-Vázquez et al. [7] found that a dose of $80 \mathrm{Mg} \mathrm{ha}^{-1}$ of solarized manure reflected a content of $2.47 \%$ organic matter $(\mathrm{OM})$ at the end of the cycle, compared to $1.61 \%$ with the inorganic fertilization treatment. Increasing the OM content contributes to nutrients of great importance for the development of the crops, and the physical properties of the soil can be improved [8]. In this sense, vermicompost is currently used as an organic substrate, and its production is carried out through biochemical and microbiological transformations of the organic matter through the digestive tract of worms [9]. This substrate, as well as municipal solid waste compost, has a high potential as a fertilizer in agriculture due to its nutritional, physical, chemical and biological characteristics, which are also reflected in the production of tomato and pepper seedlings [10], as well as pepper fruits [11], promoting a greater yield and increase in the content of photosynthetic pigments in the chili pepper crop [12].

The gained benefits after the incorporation of organic fertilizers are numerous; nevertheless, the microbiological safety of fresh products could imply a food quality risk due to the incorporation of non-composted animal manure. This is because in agricultural soils, animal manure is a known source of enteric pathogens such as Salmonella enterica serotype typhimurium [13]. In facing these concerns, alternatives to reduce the risk of contamination of crops by pathogens are being analyzed, such as by proposing the solarization of manure [14].

Therefore, the aim of this research was to evaluate organic fertilization with solarized manure (SM) and vermicompost (VC), compared with an inorganic NPK fertilizer, in the production, quality and safety of jalapeño pepper, as well as in soil properties.

\section{Materials and Methods}

\subsection{Study Site}

The study was conducted in the Agricultural Station of the Agriculture and Zootechnics Faculty of the Juarez University of the State of Durango (FAZ-UJED), located between the parallels $25^{\circ} 32^{\prime}$ and $25^{\circ} 54^{\prime} \mathrm{N}$, and meridians $103^{\circ} 19^{\prime}$ and $103^{\circ} 42^{\prime} \mathrm{W}$, in the Ejido Venecia, Gómez Palacio, Durango, Mexico (Figure 1). The altitude is $1100-1800 \mathrm{~m}$, with a rainfall of $243 \mathrm{~mm}$ and annual mean temperature of $22.1^{\circ} \mathrm{C}$ [15]. 


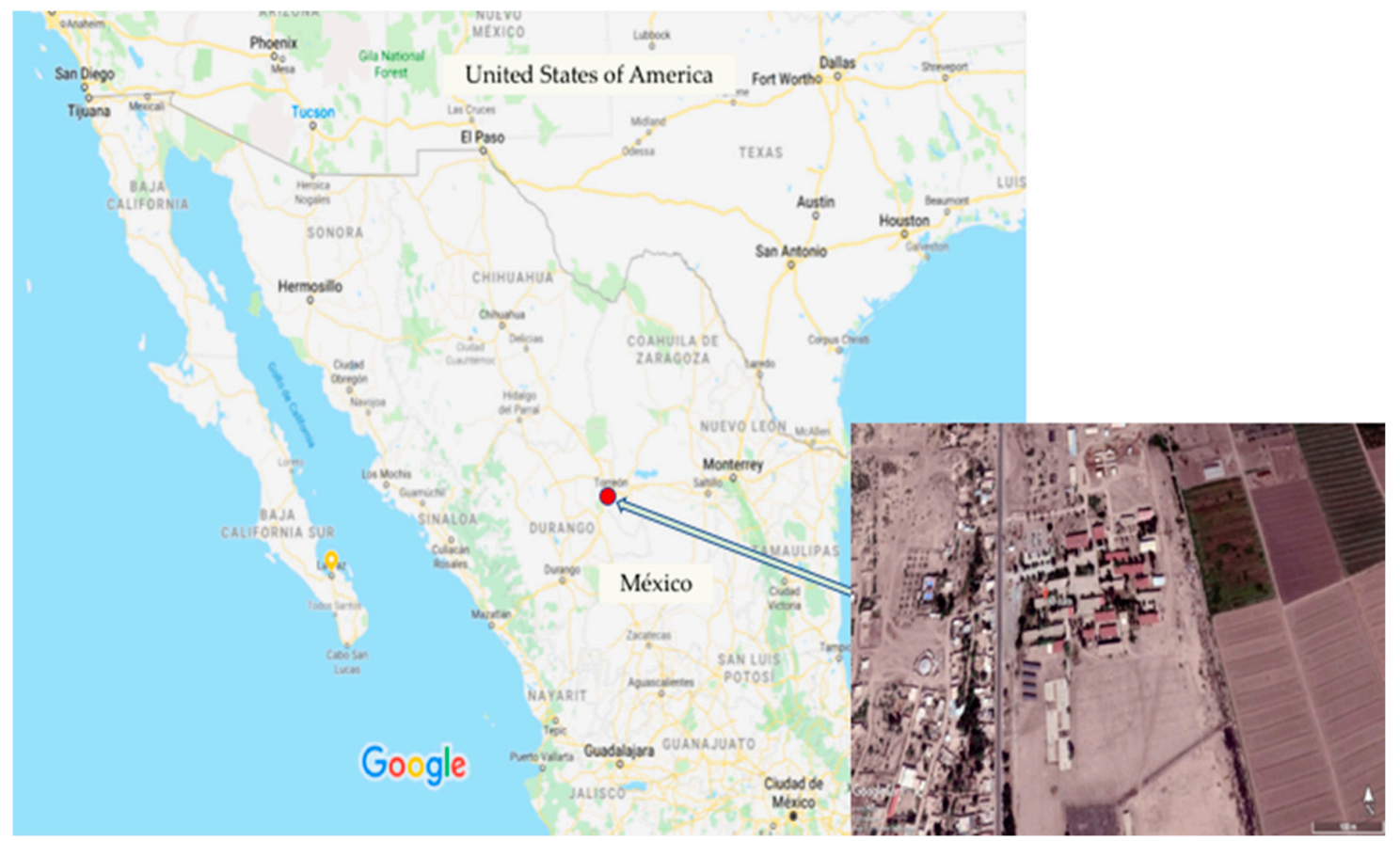

Figure 1. The geographic location of the Agriculture and Zootechnics Faculty, Juarez University of the State of Durango, northern Mexico.

\subsection{Experimental Section}

At the end of the summer agricultural season in 2014, a jalapeño pepper crop (Capsicum annuum L.) c.v. "Grande" was established to evaluate different doses of organic fertilizers. The study factors were the solarized manure (SM) and vermicompost (VC). The main soil properties at the experimental site were: the clayey texture ( $45 \%$ clay, $24 \%$ sand, $31 \%$ silt); pH: 7.8 ; EC: $4.27 \mathrm{dS} \mathrm{m}^{-1}$; OM: $2.31 \%$; inorganic N: $22.6 \mathrm{mg} \mathrm{kg}^{-1}$; and P: $16.6 \mathrm{mg} \mathrm{kg}^{-1}$. Plantlets were established on April 11th 2014; the planting systems were in a bed with a $30 \mathrm{~cm}$ distance between plants and $50 \mathrm{~cm}$ between the rows. A T-tape drip irrigation was installed and designed for an irrigation program of $6 \mathrm{~h}$ per day, every third day.

In order to carry out the manure solarization process, one-meter high piles were made with $25 \%$ humidity and covered with plastic. The time for the solarization process took one month. The SM doses were $0,40,80$ and $120 \mathrm{Mg} \mathrm{ha}^{-1}$; the doses for VC were 0 and $3 \mathrm{Mg} \mathrm{ha}^{-1}$; and the inorganic fertilizer dose was $150-100-00 \mathrm{~kg} \mathrm{ha}^{-1}$ (N-P-K), using urea and monoammonium phosphate (MAP) as source of $\mathrm{N}$ and $\mathrm{P}$, for 10 treatments with three repetitions. The experimental treatments in $\mathrm{Mg} \mathrm{ha}^{-1}$ (except NPK, in $\mathrm{kg} \mathrm{ha}^{-1}$ ) were: (1) SM 0 + VC 0, (2) SM 0 + VC 3, (3) SM 40 + VC 0, (4) SM 40 + VC 3, (5) SM 80 + VC 0, (6) SM 80 + VC 3, (7) SM 120 + VC 0, (8) SM $120+$ VC 3, (9) 150-100-00 kg ha-1 $(\mathrm{N}-\mathrm{P}-\mathrm{K})+\mathrm{VC}$, and (10) 150-100-00 $\mathrm{kg} \mathrm{ha}^{-1}(\mathrm{~N}-\mathrm{P}-\mathrm{K})+\mathrm{VC} 3$. The organic fertilizers were applied manually and incorporated with disc harrow on March 11th, 2014.

The nutrients content of the SM and VC are shown in Table 1. A commonly used digestion of compost was used to prepare the samples for analysis; this method measures all of a nutrient that is present in compost, whether it is in a plant-available form or not, so that the result is known as the total nutrient analysis. The total $\mathrm{N}$ was analyzed via the Kjeldhal method, and ammonium was determined via the distillation method [16]. The total P was analyzed by colorimetry; potassium, calcium, magnesium, sodium, molybdenum, iron, zinc and copper were analyzed in total form by atomic absorption, with digestion in a mixture of hydrochloric-perchloric acid; the $\mathrm{pH}$ and $\mathrm{EC}$ were determined in a relation of amender:water of 1:2; the organic matter was determined by calcination [17]. 
Table 1. The nutrients content of the solarized manure (SM) and vermicompost (VC).

\begin{tabular}{|c|c|c|}
\hline Chemical Composition & SM & VC \\
\hline Nitrogen (N) (as $\mathrm{N}_{\text {total }}$ ), \% & 1.12 & 1.36 \\
\hline Ammonium $\left(\mathrm{NH}^{+}\right), \mathrm{mg} \mathrm{kg}^{-1}$ & 1135.00 & 40.00 \\
\hline Phosphorus $(\mathrm{P}), \%$ & 0.35 & 0.66 \\
\hline Potassium $(\mathrm{K}), \%$ & 3.27 & 2.63 \\
\hline Calcium (Ca), \% & 3.38 & 3.47 \\
\hline Magnesium (Mg), \% & 0.71 & 0.71 \\
\hline Sodium $(\mathrm{Na}), \mathrm{mg} \mathrm{kg}^{-1}$ & 0.97 & 0.73 \\
\hline Molybdenum (Mo), $\mathrm{mg} \mathrm{kg}^{-1}$ & 560 & 5.1 \\
\hline Iron $(\mathrm{Fe}), \mathrm{mg} \mathrm{kg}^{-1}$ & 12,300 & 7800 \\
\hline Zinc (Zn), $\mathrm{mg} \mathrm{kg}^{-1}$ & 198 & 252 \\
\hline Copper $(\mathrm{Cu}), \mathrm{mg} \mathrm{kg}^{-1}$ & 45 & 112 \\
\hline $\mathrm{pH}$ & 7.6 & 9.84 \\
\hline Electrical conductivity (EC), $\mathrm{dS} \mathrm{m}^{-1}$ & 8.30 & 11.48 \\
\hline Organic matter $(\mathrm{OM}), \%$ & 54.70 & 42.36 \\
\hline
\end{tabular}

\subsection{Yield and Fruit Quality}

For the yield assessment, seven cuts of fruits were made at 50,71, 84, 94, 106, 120 and 134 days after the transplant in 12 central plants per experimental unit; for this purpose, the size of the useful plot was $8.64 \mathrm{~m}^{2}$. The quality of the fruits was evaluated according to the classification of Vázquez et al. [7], based on the length of the fruit. In order to evaluate the innocuousness of the fruits, a sampling of each of the treatments was carried out 84 days after the transplant, and a microbiological analysis was made in the Biotechnology Laboratory of FAZ-UJED. An amount of $25 \mathrm{~g}$ of jalapeño pepper ripe fruit was placed in $225 \mathrm{~mL}$ of buffered peptone water, shaken and incubated for $24 \mathrm{~h}$ at $35 \pm 2{ }^{\circ} \mathrm{C}$; subsequently, a subsample of $0.5 \mathrm{~mL}$ of each treatment was taken and placed in $10 \mathrm{~mL}$ of tetrathionate broth, before being incubated for $24 \mathrm{~h}$ at $42 \pm 0.5^{\circ} \mathrm{C}$. Later, they were seeded on brilliant green agar and incubated for $24 \mathrm{~h}$ at $35 \pm 2{ }^{\circ} \mathrm{C}$. For the colonies suspected of being Salmonella, biochemical tests were performed using lysine and iron agar (LIA), triple sugar iron (TSI), after which they were incubated for $24 \mathrm{~h}$ at $35^{\circ} \mathrm{C}$, in an Ecoshel $囚$ incubator (Ecoshel Technology Ltd., Mcallen TX USA), model 9165. The procedure followed the technique for the identification and isolation of Salmonella spp., according to the method described by the US Department of Agriculture, Food Safety and Inspection Service USDA-FSIS [18].

\subsection{Soil Analysis}

At the end of the experiment, soil samples were collected with an AMS®soil auger (AMS, Inc., American Falls, ID 83211, USA); the soil samples were taken at depths of 0-15 cm, 15-30 cm and $30-60 \mathrm{~cm}$ to determine the effect of the experimental doses of organic fertilizers on the soil. The analyzed parameters are shown in Table 2. The analytical methods were those described in the Official Mexican Standard Norm NOM-021-SEMARNAT-2000 [19].

Table 2. Methods applied for the soil analysis, according to the Standard Mexican Norm (*).

\begin{tabular}{cccc}
\hline Parameter & Abbreviation & Unit & Method \\
\hline Inorganic nitrogen & $\mathrm{N}$ & $\mathrm{mg} \mathrm{kg}^{-1}$ & $\begin{array}{c}\text { Steam drag with Devarda's alloy and } \\
\text { magnesium oxide method }\end{array}$ \\
Phosphorus & $\mathrm{P}$ & $\mathrm{mg} \mathrm{kg}^{-1}$ & Olsen method \\
Electric conductivity & $\mathrm{EC}$ & $\mathrm{dS} \mathrm{m}^{-1}$ & $\begin{array}{c}\text { Saturated extract conductivity } \\
\text { Organic matter }\end{array}$ \\
Hydrogen potential & $\mathrm{OM}$ & $\%$ & Walkley and Black method \\
Texture & $\mathrm{pH}$ & $\%$ & Potentiometer \\
Bouyoucos method
\end{tabular}

$\left.{ }^{*}\right)$ Standard Mexican Norm NOM-021-SEMARNAT-2000 [19]. 


\subsection{Experimental Design and Statistical Analysis}

The experiment that was establishment was based on a random block design with an arrangement in strips and with three replications. The data were analyzed with an analysis of variance (ANOVA) at two levels and with pair-wise comparisons, and a correlation coefficient was calculated. Statistical analyses were generated with the SAS-STAT®software (version 9.3, (C SAS Institute Inc., SAS Campus Drive, Cary, North Carolina 27513, United States of America) for Windows [20].

\section{Results and Discussion}

\subsection{Yield}

According to the ANOVA, the VC reflected a non-significant effect on the yield of the pepper crop; this may be due to the fact that the applied dose of $3 \mathrm{Mg} \mathrm{ha}^{-1}$ could be low, compared with other studies. Although in previous studies there was a significant difference in the yield of a lettuce crop when fertilizing with a dose of $20 \mathrm{Mg} \mathrm{ha}^{-1} \mathrm{VC}$ compared with a dose of $10 \mathrm{Mg} \mathrm{ha}^{-1}$ [21], in this research we applied $3 \mathrm{Mg} \mathrm{ha}^{-1}$ due to its high cost and because this dose is commonly used by the producers of the study region. Considering the averages, the SM reflected a yield of $49.6 \mathrm{Mg} \mathrm{ha}^{-1}$ with the application of $3 \mathrm{Mg} \mathrm{ha}{ }^{-1} \mathrm{VC}$, compared with the yield of $50.2 \mathrm{Mg} \mathrm{ha}^{-1}$ produced by SM without $\mathrm{VC}$; moreover, it was detected that the interaction of VC with SM evidenced non-significant differences within each harvest, whose main effects that we found are presented in Table 3. On the other hand, the doses of SM exerted a significant effect on the yield; anyway, the treatments that received $\mathrm{N}$, either as inorganic fertilizer or as manure, promoted a higher yield than the control. It is clear that the non-application of SM produced the lowest yields (33.08 and $35.69 \mathrm{Mg} \mathrm{ha}^{-1}$ ) (Table 3A); in contrast, the doses of 40 and $80 \mathrm{Mg} \mathrm{ha}^{-1}$ reflected higher yields ( 54 and $55 \mathrm{Mg} \mathrm{ha}^{-1}$ ) than that of the SM control, as well as that of the inorganic fertilizer $\left(49.6 \mathrm{Mg} \mathrm{ha}^{-1}\right)$. In sum, all doses of SM reflected a higher yield than the inorganic fertilizer, with $120 \mathrm{Mg}$ ha promoting the greatest effect, producing $56.2 \mathrm{Mg} \mathrm{ha}^{-1}$ $(p<0.05)$ (Table 3B). The obtained results coincide with those previously reported by Vázquez et al. [7], who obtained a production of 58.07 and $54.66 \mathrm{Mg} \mathrm{ha}^{-1}$ with doses of 40 and $60 \mathrm{Mg} \mathrm{ha}^{-1}$ of solarized cow manure.

The benefits of the use of manure as a fertilizer have been previously reported by other authors; in this context, Figueroa et al. [22] concluded that it is possible to partially or totally substitute the inorganic fertilizers with manure in corn forage, obtaining dry matter yields equal or greater than the ones obtained using only inorganic fertilizer. This confirms that manure can be used as a viable option to totally or partially replace inorganic fertilizers in the cultivation of different crops.

\subsection{Fruit Quality}

Fruits were collected and measured for their size-type classification (Figure 2); fruits of second quality reached the highest percentage in all the treatments, attaining up to $58 \%$ with a dose of $80 \mathrm{Mg} \mathrm{ha}^{-1} \mathrm{SM}$, which follows the fact that, on average, harvests were made every 14 days, only taking into consideration the easy detachment of the peduncle. In addition, the size corresponding to this quality is the most accepted by the food industry. First class-size quality fruits reached more than $30 \%$ in all treatments. The percentages of the third quality varied from $7.6 \%$ for the control to $12 \%$ for the dose of $80 \mathrm{Mg} \mathrm{ha}^{-1}$; however, fruits from the fourth quality (the lowest size quality for the market) did not reach $1 \%$ in any treatment. In any case, no significant differences were detected between the treatments for the different fruit qualities (Figure 3).

The obtained results coincide with those reported previously for a jalapeno pepper crop, with doses of 20, 40, 60 and $80 \mathrm{Mg} \mathrm{ha}^{-1}$ of SM and a dose of inorganic fertilization; a similar fruit quality with similar treatments was obtained; these authors reported percentages from 46.1 to $50.5 \%$ for first quality fruits, 43.4 to $46 \%$ for second quality fruits, less than $10 \%$ for third quality fruits and less than $1 \%$ for fourth quality fruits [7]. 
Table 3. A comparison of the yield means for a jalapeño pepper crop in Gómez Palacio, Durango., Mexico, in seven harvest dates and the total yield; (A): Effects of the experimental doses, (B): Effects of the organic fertilizers.

\begin{tabular}{|c|c|c|c|c|c|c|c|c|c|}
\hline \multicolumn{2}{|c|}{ Doses } & \multicolumn{7}{|c|}{ Number of Harvests } & \multirow{4}{*}{$\begin{array}{c}\text { Total } \\
\text { Yield } \\
\text { Mg ha }^{-1}\end{array}$} \\
\hline SM & VC & 1 & 2 & 3 & 4 & 5 & 6 & 7 & \\
\hline \multirow{2}{*}{\multicolumn{2}{|c|}{$\mathrm{Mg} \mathrm{ha}^{-1}$}} & \multicolumn{7}{|c|}{ Days after Transplant } & \\
\hline & & 50 & 71 & 84 & 94 & 106 & 120 & 134 & \\
\hline \multirow{3}{*}{0} & & & & A: Effect & experim & al doses & & & \\
\hline & 0 & 0.78 & 1.08 & 6.02 & 7.90 & 6.55 & 6.64 & 4.11 & 33.08 \\
\hline & 3 & 0.91 & 1.54 & 6.13 & 7.30 & 8.82 & 7.28 & 3.71 & 35.69 \\
\hline \multirow[t]{2}{*}{40} & 0 & 1.34 & 1.93 & 9.97 & 10.06 & 11.18 & 10.64 & 9.88 & 54.99 \\
\hline & 3 & 1.17 & 2.84 & 9.92 & 9.91 & 10.34 & 11.26 & 8.08 & 53.52 \\
\hline \multirow[t]{2}{*}{80} & 0 & 1.48 & 2.73 & 10.07 & 10.98 & 11.68 & 11.29 & 8.83 & 57.07 \\
\hline & 3 & 1.17 & 2.66 & 9.51 & 10.67 & 11.35 & 11.08 & 6.54 & 52.97 \\
\hline \multirow[t]{2}{*}{120} & 0 & 1.27 & 1.81 & 9.49 & 11.02 & 13.01 & 9.03 & 10.66 & 56.28 \\
\hline & 3 & 1.58 & 3.83 & 8.99 & 11.26 & 10.21 & 12.74 & 7.45 & 56.06 \\
\hline \multirow[t]{2}{*}{ 150-100-00 } & 0 & 1.06 & 2.20 & 8.58 & 10.05 & 10.63 & 8.20 & 8.76 & 49.47 \\
\hline & 3 & 0.80 & 1.71 & 7.37 & 9.99 & 9.87 & 13.06 & 6.99 & 49.77 \\
\hline \multicolumn{10}{|c|}{ B: Effects of organic fertilizers } \\
\hline \multirow[t]{2}{*}{$\mathrm{VC}$} & 0 & 1.19 & 1.95 & 8.82 & 10.00 & 10.61 & 9.16 & 8.45 & 50.18 \\
\hline & 3 & 1.12 & 2.52 & 8.38 & 9.83 & 10.12 & 11.08 & 6.55 & 49.61 \\
\hline \multirow{4}{*}{ SM } & 0 & $0.84 \mathrm{c}$ & $1.31 \mathrm{~b}$ & $6.08 \mathrm{c}$ & $7.60 \mathrm{~b}$ & $7.69 \mathrm{~b}$ & $6.96 \mathrm{~b}$ & $3.91 \mathrm{~b}$ & $34.39 c$ \\
\hline & 40 & $1.25 \mathrm{ab}$ & $2.39 \mathrm{ab}$ & $9.95 \mathrm{a}$ & $9.98 \mathrm{a}$ & $10.76 \mathrm{a}$ & $10.95 \mathrm{a}$ & $8.98 \mathrm{a}$ & $54.26 \mathrm{ab}$ \\
\hline & 80 & $1.33 \mathrm{a}$ & $2.69 \mathrm{a}$ & $9.79 \mathrm{ab}$ & $10.82 \mathrm{a}$ & $11.52 \mathrm{a}$ & $11.19 \mathrm{a}$ & $7.68 \mathrm{ab}$ & $55.02 \mathrm{ab}$ \\
\hline & 120 & $1.42 \mathrm{a}$ & $2.82 \mathrm{a}$ & $9.24 \mathrm{ab}$ & $11.14 \mathrm{a}$ & $11.61 \mathrm{a}$ & $10.89 \mathrm{a}$ & $9.05 \mathrm{a}$ & $56.17 \mathrm{a}$ \\
\hline Inorganic & $150-100-0$ & $0.93 \mathrm{bc}$ & $1.95 \mathrm{ab}$ & $7.97 \mathrm{~b}$ & $10.02 \mathrm{a}$ & $10.25 \mathrm{a}$ & $10.63 \mathrm{a}$ & $7.87 \mathrm{ab}$ & $49.62 \mathrm{~b}$ \\
\hline
\end{tabular}




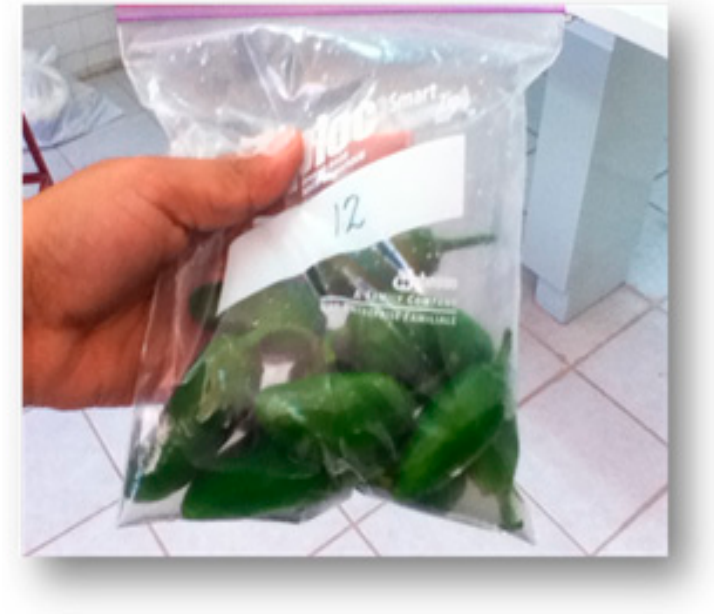

(a)

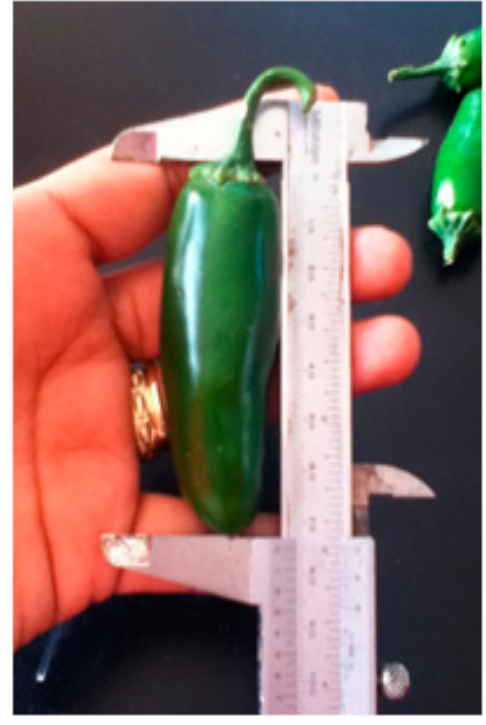

(b)

Figure 2. Sampling (a) and measurement (b) of fruits for the yield and size-quality classification.

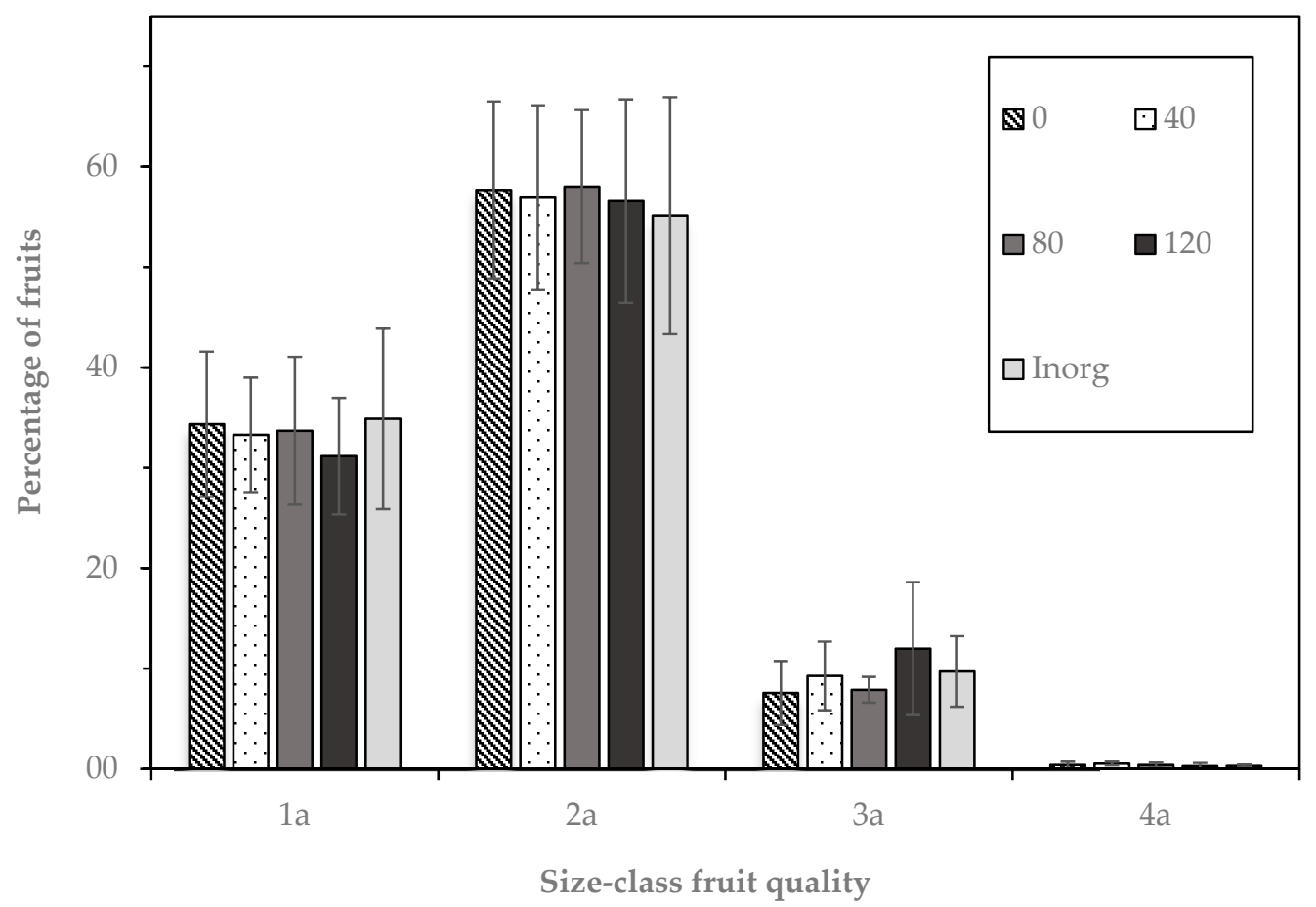

Figure 3. The percentage of the size-class quality of harvested fruits and the differences between the solarized manure treatments.

\subsection{Safety}

The presence of the pathogenic bacteria Salmonella spp. was not detected in the analyzed fruit samples, which allows for the interpretation that solarization is a process that is useful for eliminating this pathogen. This evidence matches with a previous study, which reported that the thermophilic solarization of manure is an effective active method for the control of manure-borne pathogens; this means that if the technique is applied correctly, the pathogen content in the original material decreases drastically [23]. 


\subsection{Soil Properties}

The effect of the VC on the evaluated soil variables was not significant, possibly because the applied dose was only $3 \mathrm{Mg} \mathrm{ha}^{-1}$. In contrast, other researchers found that the $\mathrm{N}$ and P content in soil increased significantly with a dose of $15 \mathrm{Mg} \mathrm{ha}^{-1}$ of VC in a tomato crop, compared to non-fertilized plots [24]. Given that the application of VC did not generate significant effects, the results are shown as averages of the SM main effects. The values of the $\mathrm{pH}$ varied from 7.8 to 8.1 at different depths and treatments. The highest $\mathrm{pH}$ value (8.1) was obtained with $120 \mathrm{Mg} \mathrm{ha}^{-1} \mathrm{SM}$, and the lowest values (7.8) were observed for the control, the treatment with a dose of $40 \mathrm{Mg} \mathrm{ha}^{-1}$, and with the inorganic fertilization. At a depth of $0-15 \mathrm{~cm}$, the $\mathrm{pH}$ values were 7.8 for the control, the $40 \mathrm{Mg} \mathrm{ha}^{-1}$ dose, and with the inorganic fertilization, and they reached 7.9 with $80 \mathrm{Mg} \mathrm{ha}^{-1}$ and $120 \mathrm{Mg} \mathrm{ha}^{-1}$ doses (Table 4). The increase in $\mathrm{pH}$ may result from the applied manure doses, since other authors reported an increase in the soil $\mathrm{pH}$ when evaluating the effectiveness of 10 organic fertilizers in wheat (Triticum aestivum) c.v. Batán F96 [25]. The results suggest that, although the highest doses of SM ( 80 and $\left.120 \mathrm{Mg} \mathrm{ha}^{-1}\right)$ showed the highest $\mathrm{pH}$ values, this was not enough evidence to change the classification of the soil; hence, the study soil was classified as moderately alkaline in the different treatments, according to the Standard Mexican Norm NOM-021-RECNAT-2000 [19].

Table 4. A comparison of the means of the soil variables at the end of the 2014 summer agricultural season in a jalapeño pepper crop with SM and inorganic fertilizers; Gómez Palacio, Durango., Mexico.

\begin{tabular}{|c|c|c|c|c|c|}
\hline $\begin{array}{l}\text { SM and NPK Doses/Depth } \\
\text { of Sampling }\end{array}$ & $\mathrm{pH}$ & $\begin{array}{c}\mathrm{EC} \\
\mathrm{dS} \mathrm{m}^{-1}\end{array}$ & $\begin{array}{c}\mathrm{N} \\
\mathrm{mg} \mathrm{kg}^{-1}\end{array}$ & $\begin{array}{c}\mathbf{P} \\
\mathrm{mg} \mathrm{kg}^{-1}\end{array}$ & $\begin{array}{c}\mathrm{OM} \\
\%\end{array}$ \\
\hline \multicolumn{6}{|l|}{ Control } \\
\hline 0-15 & $7.8 \mathrm{a}$ & $5.9 \mathrm{a}$ & $31.9 \mathrm{a}$ & $46.4 \mathrm{ab}$ & $2.6 \mathrm{a}$ \\
\hline $15-30$ & $7.9 \mathrm{a}$ & $2.5 \mathrm{a}$ & $12.6 \mathrm{a}$ & $16.4 \mathrm{ab}$ & $1.5 \mathrm{ab}$ \\
\hline $30-60$ & $8.0 \mathrm{a}$ & $3.7 \mathrm{a}$ & $6.6 \mathrm{a}$ & $3.6 \mathrm{a}$ & $2.6 \mathrm{a}$ \\
\hline \multicolumn{6}{|l|}{$40 \mathrm{Mg} \mathrm{ha}^{-1}$} \\
\hline 0-15 & $7.8 \mathrm{a}$ & $4.9 \mathrm{a}$ & $36.2 \mathrm{a}$ & $45.9 \mathrm{ab}$ & $3.3 \mathrm{a}$ \\
\hline $15-30$ & $7.9 \mathrm{a}$ & $2.3 \mathrm{a}$ & $13.5 \mathrm{a}$ & $17.5 \mathrm{ab}$ & $1.5 \mathrm{ab}$ \\
\hline $30-60$ & $8.0 \mathrm{a}$ & $3.6 \mathrm{a}$ & $7.7 \mathrm{a}$ & $3.2 \mathrm{a}$ & $3.0 \mathrm{a}$ \\
\hline \multicolumn{6}{|l|}{$80 \mathrm{Mg} \mathrm{ha}^{-1}$} \\
\hline 0-15 & $7.9 \mathrm{a}$ & $4.9 \mathrm{a}$ & $32.3 \mathrm{a}$ & $56.3 \mathrm{ab}$ & $3.6 \mathrm{a}$ \\
\hline $15-30$ & $7.9 \mathrm{a}$ & $2.8 \mathrm{a}$ & $16.3 \mathrm{a}$ & $25.9 \mathrm{a}$ & $1.7 \mathrm{a}$ \\
\hline $30-60$ & $7.9 \mathrm{a}$ & $4.0 \mathrm{a}$ & $8.6 \mathrm{a}$ & $3.9 \mathrm{a}$ & $2.9 \mathrm{a}$ \\
\hline \multicolumn{6}{|l|}{$120 \mathrm{Mg} \mathrm{ha}^{-1}$} \\
\hline 0-15 & $7.9 \mathrm{a}$ & $5.3 \mathrm{a}$ & $38.6 \mathrm{a}$ & $70.7 \mathrm{a}$ & $3.7 \mathrm{a}$ \\
\hline $15-30$ & $7.8 \mathrm{a}$ & $2.5 \mathrm{a}$ & $13.7 \mathrm{a}$ & $16.5 \mathrm{ab}$ & $1.3 \mathrm{ab}$ \\
\hline $30-60$ & $8.1 \mathrm{a}$ & $4.2 \mathrm{a}$ & $6.3 \mathrm{a}$ & $4.3 \mathrm{a}$ & $2.6 \mathrm{a}$ \\
\hline \multicolumn{6}{|l|}{$150-100-00$} \\
\hline 0-15 & $7.8 \mathrm{a}$ & $4.3 \mathrm{a}$ & $34.6 \mathrm{a}$ & $17.1 \mathrm{~b}$ & $2.6 \mathrm{a}$ \\
\hline $15-30$ & $7.9 \mathrm{a}$ & $1.8 \mathrm{a}$ & $5.9 \mathrm{a}$ & $5.5 \mathrm{~b}$ & $1.1 \mathrm{~b}$ \\
\hline $30-60$ & $8.0 \mathrm{a}$ & $4.0 \mathrm{a}$ & $9.0 \mathrm{a}$ & $5.1 \mathrm{a}$ & $2.8 \mathrm{a}$ \\
\hline
\end{tabular}

According to the classification proposed by Castellanos [26], the analyzed soil is a saline type, since the EC oscillated from 4.3 to $5.9 \mathrm{dS} \mathrm{m}^{-1}$ at a depth of $0-15 \mathrm{~cm}$. For the $15-30 \mathrm{~cm}$ depth, we found a moderately saline soil for the different treatments, except for the soil with inorganic fertilization, which reflected a value of $1.8 \mathrm{dS} \mathrm{m}^{-1}$, corresponding to a soil with very low content of salts (Table 4). The increase in EC with organic fertilizers was also reported for the production of cucumber fertilized with different organic substrates (solarized cow manure, solarized goat manure and vermicompost), where the salt content increased as the decomposition of the substrates progressed, causing a notable increase in its concentration and in the EC value. In this case, because a drip irrigation was applied, the highest moisture content was found in the upper layer of the soil, which explains why the highest EC values were found at a $0-15 \mathrm{~cm}$ depth [27]. The highest $O M$ value that was found was $3.7 \%$ at a depth of 0 to $15 \mathrm{~cm}$ with a dose of $120 \mathrm{Mg} \mathrm{ha}^{-1}$ of SM, and the lowest value was $1.1 \%$ at a depth of 
15-30 cm with the dose of inorganic fertilization (Table 4). The increase of soil OM is related to the incorporation of manure doses; other authors found that a soil with organic amendments in the form of SM caused a significant difference in the stability of its aggregates due to the percentage of OM and other agglutinating agents present in the soil compared to a soil without amendments [28].

In this study, the increase in the OM content corresponds to $0.7 \%$ with a dose of $40 \mathrm{Mg} \mathrm{ha}^{-1}$, $1 \%$ with a dose of $80 \mathrm{Mg} \mathrm{ha}^{-1}$, and $1.1 \%$ with a dose of $120 \mathrm{Mg} \mathrm{ha}^{-1}$, compared to the control; this increase in the soil OM content coincides with the values reported by Trejo-Escareño et al. [29], who reported an increase of $1 \%$ in the OM content compared to the control at the end of the first year, after applying doses of 40, 80, 120 and $160 \mathrm{Mg} \mathrm{ha}^{-1}$ of cattle manure as fertilizer for the production of corn forage. A quadratic numerical model expressing the OM increases as a function of the SM doses was derived (Figure 4).

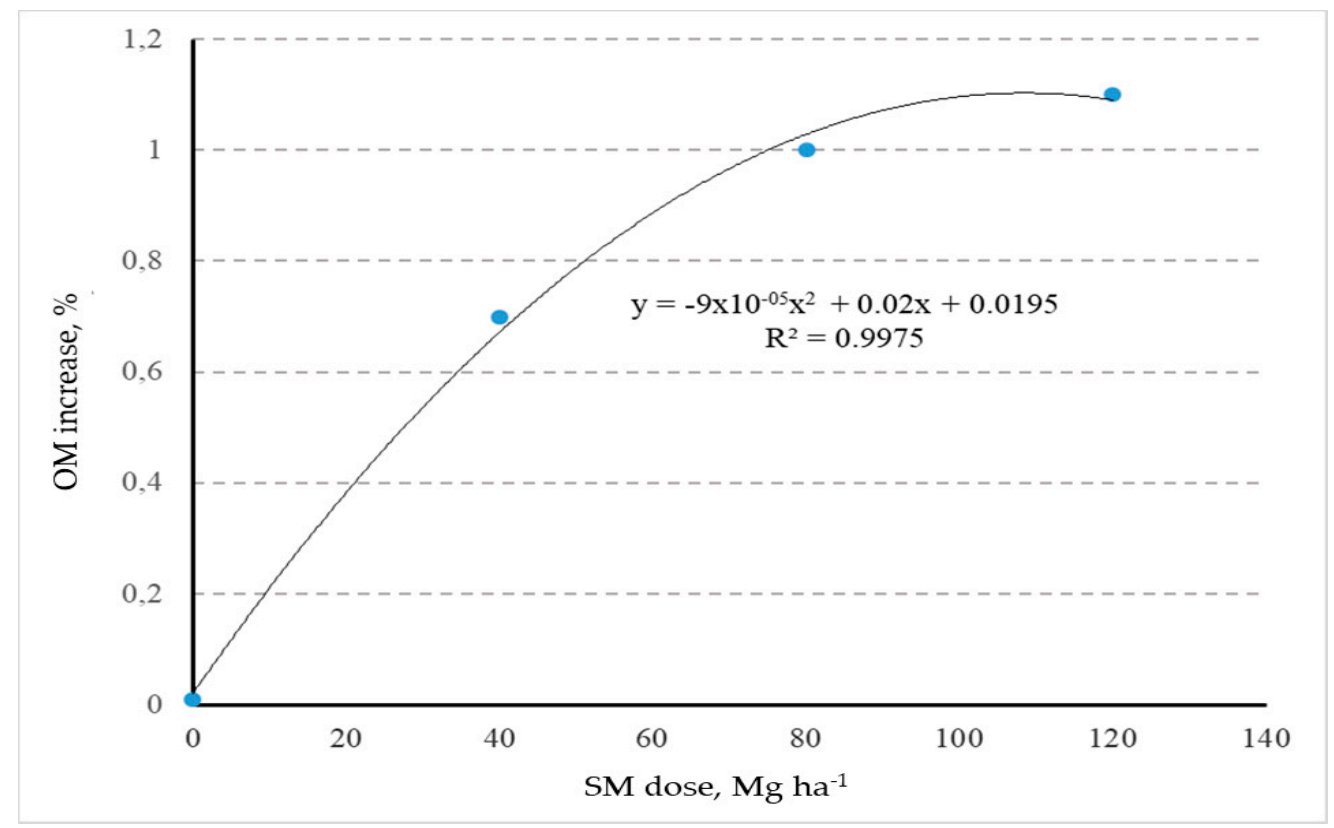

Figure 4. Preliminary quadratic function expressing the effect of $\mathrm{SM}$ doses $\left(\mathrm{Mg} \mathrm{ha}^{-1}\right)$ on $\mathrm{OM}$ increases (\%).

At the same time, the $\mathrm{N}$ content reflected a non-significant effect, reaching its highest values from 31.9 to $38.6 \mathrm{mg} \mathrm{kg}^{-1}$ at a $0-15 \mathrm{~cm}$ depth, with a tendency to decrease with depth, with values from 5.9 to $16.3 \mathrm{mg} \mathrm{kg}^{-1}$ at $15-30 \mathrm{~cm}$, and 6.3 to $9.0 \mathrm{mg} \mathrm{kg}^{-1}$ at $30-60 \mathrm{~cm}$ (Table 4). Similar results were reported by the mentioned authors, who, after ten years of application of manure for the production of fodder corn, found average nitrate values of $23.4,37.8,39.8$ and $43.3 \mathrm{mg} \mathrm{kg}^{-1}$ in soil samples fertilized with doses of 40,80,120 and $160 \mathrm{Mg} \mathrm{ha}^{-1}$ [29]. On the other hand, the highest $\mathrm{P}$ content was detected for a $0-15 \mathrm{~cm}$ depth, with values from 17.1 to $70.7 \mathrm{mg} \mathrm{kg}^{-1}$, similarly to $\mathrm{N}$. The P concentrations varied according to the depth, varying from 5.5 to $25.9 \mathrm{mg} \mathrm{kg}^{-1}$ at a $15-30 \mathrm{~cm}$ depth and 3.2 to $5.1 \mathrm{mg} \mathrm{kg}^{-1}$ at a 30-60 cm depth (Table 4).

\section{Conclusions}

The nutrients provided to the soil by the applied doses of SM are enough to satisfy the studied jalapeno crop needs. It is important to mention that the reached yield with a dose of $120 \mathrm{Mg} \mathrm{ha}{ }^{-1}$ was significantly higher than that of the inorganic fertilization. Nevertheless, the applied doses of VC showed a non-significant contribution to the yield under the prevailing soil conditions.

The practice of fertilization with organic amendments allowed for the development of fruits with a commercial quality that compete directly in the market with fruits conventionally produced with inorganic fertilization. 
The results of the assayed microbiological analyses suggest that the applied method for the solarization of manure is effective for controlling and eliminating colonies of the pathogenic bacteria Salmonella spp.

Author Contributions: Conceptualization, E.S.-S., J.L.G.-H. and A.A.V.-G.; methodology, E.S.-S. and M.Á.G.-R; software, I.O.-C. and M.Á.G.-R.; validation, U.F.-V, E.T.-D. and A.A.V.-G.; formal analysis, E.T.-D., A.A.V.-G. and J.L.G.-H.; investigation, E.S.-S. and U.F.-V.; resources, I.O.-C.; data curation and analysis, A.A.V.-G. and E.T.-D.; writing—original draft preparation, A.A.V.-G., E.S.-S. and U.F.-V.; writing—review and editing, E.T.-D.; visualization, J.L.G.-H.; supervision, U.F.-V. and E.S.-S.; project administration, I.O.-C. and M.Á.G.-R..; funding acquisition, E.S.-S. and I.O.-C.

Funding: This research was supported by the National Council of Science and Technology of México (CONACYT), postgraduate grant number to CVU 252979.

Acknowledgments: Ana Alejandra Valenzuela-García acknowledges financial support given by the National Council for Science and Technology of Mexico (CONACYT) for graduate study. Authors thank the technical assistance of the Water and Soil Analysis Laboratory technicians of FAZ_UJED, and the Lab technicians of CIBNOR SC (La Paz, BCS). Administrative support was given by the Graduate Studies and Research Division staff of FAZ-UJED.

Conflicts of Interest: The authors declare no conflict of interest of any kind; the funders had no role in the design and implementation of this research and its data interpretation, nor in the decision to write and submit this manuscript.

\section{References}

1. FAOSTAT. Food and Agriculture Organization of the United Nations. Production Module (Modulo Producción). 2016. Available online: http://faostat.fao.org/site/339/default.aspx (accessed on 19 February 2016).

2. Atlas Agroalimentario. Ministry of Agriculture and Rural Development. Edition 2018. Available online: https://nube.siap.gob.mx/gobmx_publicaciones_siap/pag/2018/Atlas-Agroalimentario-2018 (accessed on 7 December 2018).

3. SAGARPA. Ministry of Agriculture, Livestock, Rural Development, Fisheries and Food. Edition 2016. Available online: https://nube.siap.gob.mx/cierreagricola/ (accessed on 24 November 2016).

4. SIAP. Agrifood and Fisheries Information Service (Servicio de Información Agroalimentaria). Database. 2016. Available online: http://infosiap.siap.gob.mx/aagricola_siap_gb/icultivo/index.jsp (accessed on 1 November 2016).

5. Zayed, M.S.; Hassanein, M.K.K.; Esa, N.H.; Abdallah, M.M.F. Productivity of pepper crop Capsicum annuum L. as affected by organic fertilizer, soil solarization and endomycorrhizae. Ann. Agric. Sci. (AOAS) 2013, 58, 131-137. [CrossRef]

6. García-Hernández, J.L.; Valdez-Cepeda, R.D.; Murillo-Amador, B.; Nieto-Garibay, A.; Beltrán-Morales, L.F.; Magallanes-Quintanar, R.; Troyo-Diéguez, E. Compositional nutrient diagnosis and main nutrient interactions in yellow pepper grown on desert calcareous soils. J. Plant Nutr. Soil Sci. 2004, 167, 509-515. [CrossRef]

7. Vázquez-Vázquez, C.; García-Hernández, J.L.; Salazar-Sosa, E.; López-Martínez, J.D.; Valdez-Cepeda, R.D.; Orona-Castillo, I.; Gallegos-Robles, M.A.; Preciado-Rangel, P. Aplicación de estiércol solarizado al suelo y la producción de chile jalapeño Capsicum annuum L. Rev. Chapingo Ser. Hortic. 2011, 17, 69-74. [CrossRef]

8. Walker, D.J.; Bernal, M.P. The effect of olive mill waste compost and poultry manure on the availability and plant uptake of nutrients in a high saline soil. Bioresour. Technol. 2008, 99, 396-403. [CrossRef] [PubMed]

9. De la Cruz-Lázaro, E.; Osorio-Osorio, R.; Martínez-Moreno, E.; Lozano del Río, A.J.; Gómez-Vázquez, A.; Sánchez-Hernández, R. Use of composts and vermicomposts for the organic production of tomato in greenhouse. Interciencia 2010, 35, 363-368.

10. Rodríguez-Canché, L.G.; Cardoso-Vigueros, L.; Carvajal-León, J.; de la, C.; Poot Dzib, S. Production of habanero pepper seedlings with vermicompost generated from sewage sludge. Compost Sci. Util. 2010, 18, 42-46. [CrossRef]

11. Tzortzakis, N.; Gouma, S.; Dagianta, E.; Saridakis, C.; Papamichalaki, M.; Goumas, D.; Manios, T. Use of fertigation and municipal solid waste compost for greenhouse pepper cultivation. Sci. World J. 2012, 2012, 973193. [CrossRef] [PubMed]

12. Berova, M.; Karanatsidis, G.; Sapundzhieva, K.; Nikolova, V. Effect of organic fertilization on growth and yield of pepper plants Capsicum annuum L. Folia Hortic. 2013, 22, 3-7. [CrossRef] 
13. Ongeng, D.; Muyanja, C.; Geeraerd, A.H.; Springael, D.; Ryckeboer, J. Survival of Escherichia coli O157:H7 and Salmonella enterica serovar Typhimurium in manure and manure-amended soil under tropical climatic conditions in Sub-Saharan Africa. J. Appl. Microbiol. 2011, 110, 1007-1022. [CrossRef] [PubMed]

14. Cimen, I.; Turgay, B.; Pirinc, V. Effect of solarization and vesicular arbuscular mychorrizal on weed density and yield of lettuce Lactuca sativa L. in autumn season. Afr. J. Biotechnol. 2010, 9, 3520-3526. [CrossRef]

15. National Institute of Statistics and Geography (Instituto Nacional de Estadística y Geografía). Prontuario de información geográfica municipal de los Estados Unidos Mexicanos, Gómez Palacio, Durango, México. Clave geoestadística 10007. 2016. Available online: http://www3.inegi.org.mx/sistemas/mexicocifras/ datosgeograficos/10/10007.pdf (accessed on 2 February 2017).

16. Page, A.L.; Miller, R.H.; Keeney, D.R. Methods of Soil Analysis. Part 2: Chemical and Microbiological Properties, 2nd ed.; Agronomy No. 9; American Society of Agronomy Inc.; Soil Science Society of America Inc.: Madison, WI, USA, 1982.

17. Peters, J. Recommended Methods of Manure Analysis; A3769; University of Wisconsin: Madison, WI, USA, 2003; 57p, Available online: https://soils.wisc.edu/extension/pubs/A3769.pdf (accessed on 3 February 2017).

18. US Department of Agriculture, Food Safety and Inspection Service (USDA-FSIS). Isolation and Identification of Salmonella from Meat, Poultry, Pateurized Egg and Siluriformes (fish) Products. 2016. Available online: https://www.fsis.usda.gov/wps/wcm/connect/700c05fe-06a2-492a-a6e1-3357f7701f52/MLG-4.pdf? MOD=AJPERES (accessed on 23 May 2017).

19. SEMARNAT. Ministry of the Environment and Natural Resources (Secretaría de Medio Ambiente y Recursos Naturales). Norma Oficial Mexicana NOM-021-SEMARNAT-2000. 2002. Available online: http: //biblioteca.semarnat.gob.mx/janium/Documentos/Ciga/libros2009/021.pdf (accessed on 1 November 2017).

20. SAS Version 9.3, SAS Institute: Cary, NC, USA, 2010.

21. Ferreras, L.; Gomez, E.; Toresani, S.; Firpo, I.; Rotondo, R. Effect of organic amendments on some physical, chemical and biological properties in a horticultural soil. Bioresour. Technol. 2006, 97, 635-640. [CrossRef] [PubMed]

22. Figueroa-Viramontes, U.; Cueto-Wong, J.A.; Delgado, J.A.; Núñez-Hernández, G.; Reta-Sánchez, D.G.; Quiroga-Garza, H.M.; Faz-Contreras, R.; Márquez-Rojas, J.L. Estiércol de bovino lechero sobre el rendimiento y recuperación aparente de nitrógeno en maíz forrajero. Terra Latinoam. 2010, 28, 361-369.

23. Vazquez-Vazquez, C.; Gallegos-Robles, M.A.; Salazar-Sosa, E.; Orona-Castillo, I.; García-Hernandez, J.L.; Trejo-Escareño, H.I.; Mendoza-Retana, S.S. Manure solarization from cattle, goat and poultry and its effect on survival of Salmonella spp. J. Pure Appl. Microbiol. 2015, 9, 151-158.

24. Azarmi, R.; Giglou, M.T.; Taleshmikail, R.D. Influence of vermicompost on soil chemical and physical properties in tomato Lycopersicum esculentum field. Afr. J. Biotechnol. 2008, 7, 2397-2401. [CrossRef]

25. Álvarez-Sánchez, E.; Vázquez-Alarcón, A.; Castellanos, J.Z.; Cueto-Wong, J. Efectividad biológica de abonos orgánicos en el crecimiento de trigo. Terra Latinoam. 2006, 24, 261-268.

26. Castellanos, J.Z. Manual de interpretación de análisis de suelos y aguas, 2nd ed.; Intagri: Celaya, Guanajuato, México, 2000; 201p.

27. Fortis-Hernández, M.; Sánchez-Tapia, C.; Preciado-Rangel, P.; Salazar-Sosa, E.; Segura-Castruita, M.A.; Orozco-Cidal, J.A.; Chavarría-Glicia, J.; Trejo-Valencia, R. Sustratos orgánicos tratados para producción de pepino Cucumis sativus L. bajo sistema protegido. Cienc. Tecnol. Agropecu. Méx. 2013, 1, 1-7.

28. Flores-Sánchez, B.; Segura-Castruita, M.A.; Fortis-Hernández, M.; Martínez-Corral, L.; Aldaco-Nuncio, R.A.; Orozco-Vidal, J.A. Enmiendas de estiércol solarizado en la estabilidad de agregados de un aridisol cultivado de México. Rev. Mex. Cienc. Agríc. 2015, 6, 1543-1555. [CrossRef]

29. Trejo-Escareño, H.I.; Salazar-Sosa, E.; López-Martínez, J.D.; Vázquez-Vázquez, C. Impacto del estiércol bovino en el suelo y producción de forraje de maíz. Rev. Mex. Cienc. Agríc. 2013, 4, 727-738. [CrossRef]

(C) 2019 by the authors. Licensee MDPI, Basel, Switzerland. This article is an open access article distributed under the terms and conditions of the Creative Commons Attribution (CC BY) license (http://creativecommons.org/licenses/by/4.0/). 